$\xi=-1$

\title{
Complexity as an Antecedent for External Collaboration in New Product Development Projects
}

\author{
Reza Gheshmi ${ }^{1}$, Hugo Zacro ${ }^{2}$, Frederic Marimon ${ }^{3}$ \\ ${ }^{1}$ Universitat internacional de catalunya \\ ${ }^{2}$ School of Business and Engineering- La Salle University \\ ${ }^{3}$ Universitat internacional de catalunya
}

\begin{abstract}
This study examines how project complexity in low technology-intensive small- and medium-sized enterprises (SMEs) contribute in implementation of open innovation practices, during their new product development projects. The main focus of this paper is to investigate the critical role of complexity in the project level to identifying the compatibility of those external sources involved in NPD. The low technology-intensive sector in Spain were chosen as a target context, there were many innovative SMEs operating in these industries and because these sectors were going through significant changes. Four external knowledge sources, Universities, suppliers, customers and competitors and four open innovation practices, Community, Platform, Partnership and seller-buyer agreement, in the new product development were identified. The study shows that in SMEs, project complexity plays an important role in selecting the external source and implementation of open innovation practices. The main conclusion of the study is that the external collaboration in new product development projects is determined by different dimensions of project complexities and in projects with different type of complexity, the SMEs follow different external knowledge sources and open innovation practices. The study results imply that SMEs benefit from opening up their innovation process in the new product development projects. The firms in this study employed a blend of strategies that is more compatible with dimensions of project complexity. They collaborated actively with different external knowledge source and different modes of collaboration, when they have determination of different dimensions of project complexity. Also, the study extends understanding of the strategic use of open innovation in SMEs by demonstrating how SMEs balance the risk of project complexity built on new product development and the benefit of creating a wider capability base with partnerships.
\end{abstract}

Keywords: SME, New product development, Open innovation practices, Collaboration strategies, Collaboration modes.

\section{Introduction}

New product development (NPD) refers to a focal point in competition that leads to many advantages, including higher product quality and a shorter time to market. Organizations are able to reach markets faster and more efficiently and might succeed in generating a sustainable competitive advantage that is not easy for their rivals to imitate. Therefore, NPD results not just in access to new markets but also in improvements to the competitiveness of companies and facilitates relationships with other firms (Veliyath et al., 2000). One of the main issues is the necessity to mobilize not only internal resources but also external actors in new product development. Thus, the process of development entails a series of actions that cut across many different functions, both external and internal, of an organization, and an increase in product performance and technological complexity will build relationships with important suppliers to contribute to the success of any organization. Regarding the advantages of integrating external innovation sources into the NPD process, many companies utilize a Japanesestyle policy for their suppliers. When they become responsible for designing the whole system as well as subassemblies, they are integrated systematically into the design and production process of the organization (Bell, 1999; Chesbrough et al., 2006; Karmarkar, 2004; Schulttze and Stabell, 2004; Tidd and Hull, 2003). Therefore, the innovative bonds among a lead manufacturer and the nearby group of external suppliers play a key role in generating flexibility, and they are assumed to be the main key to better products as well as a shorter development cycle (Ireland et al., 2002).

Collaborating not just with suppliers but generally with any external sources is accepted to increase organizational learning (Inkpen and Tsang, 2005; Powell et al., 1996), and, because new knowledge is usually retrieved from outside an organization, interorganizational relationships are critical (March, 1991). This is the same idea as that put forward in previous studies on open innovation, in which inbound open innovation was considered to be an important factor for innovation (Chesbrough, 2003). Open innovation has been described as the use of purposive outflows and inflows of knowledge to improve internal innovation and to expand the markets for using innovation externally (Chesbrough, 2003; Van de Vrande et al 2013). A great deal of attention has been paid to open innovation during the past years (Chesbrough et al., 2006; Elmquist et al 2009; West and Bogers, 2014; West et al 2014). Open innovation researchers have emphasized the need for focal firms to transcend their boundaries through external technology and knowledge sourcing. The current study discusses innovation complexity, environmental uncertainty and knowledge recombination as resulting in enhanced permeability of the boundaries in an organization and the need for them to interact more openly with external stakeholders and the environment (Karl-Heinz, 2015). The idea of open innovation includes a broad range of external factors, such as users, suppliers, customers, competitors and universities. The underlying mechanism to achieve external 
knowledge and generate open innovation in turn covers a broad range of alternatives, such as tournaments and contests, joint ventures and alliances, licensing, corporate venture capital, open source platforms and participation in different development communities.

Researchers have recently begun to consider the governance implications of open innovation (West Et al 2014). Generally, the results have demonstrated that improved relationships and knowledge flows from different external partners, particularly in uncertain contexts, produce better innovation consequences (Chesbrough, 2006; Lichtenthaler and Ernst, 2009). In addition to such an emphasis on the number or breadth of externalities, still other investigations have revealed the advantages of interacting with certain external constituents, for example including suppliers (Hakansson and Eriksson, 1993; Handfield and Lawson, 2007; Petersen et al, 2003; Ragatz et al., 2002), customers (AtuaheneGima, 1995; Cooper and Kleinschmidt, 1987; Hippel, 1978), competitors (Hamel, 1991) and universities (Gerwin et al., 1992; Santoro, 2000) in the innovation process. Although the need to improve the access to external knowledge and to achieve greater openness in new product development projects is still compelling, the managerial and comparative governance implications of such a discussion are not clear yet. The mentioned study concentrates on aggregates on the form level, such as how specific aggregate quantities or types of external relations or governance forms could result in more innovation (Chesbrough, 2006; Lichtenthaler and Ernst, 2009).

However, any kind of prescription or advice on the organizationallevel aggregates (which is for the entire organization to employ remarkably more open governance forms) could result in misspecified solutions for governance at the micro level. Most of the studies in fields of collaborative innovation and search strategies have emphasized the understanding of an "optimal" amount of external partners (Laursen and Salter, 2006, Bianchi et al 2013) and the critical role of various kinds of external sources (Laursen and Salter, 2006; Nieto and Santamaría, 2007). The most remarkable similarity between such investigations is that all of the analyses are on the organizational level, which shows that collaboration and searches are considered as decisions made for the organization as a whole and not decisions made according to the needs of certain NPD projects. The main goal of this paper is to focus on the critical role of complexity in the project level to identifying the compatibility of those external sources involved in NPD, like other research, and in determining whether the decision to include external sources is made on a project-by-project basis (Bahemia and Squire, 2010; Bonesso et al., 2011). To our knowledge, few studies have focused on the impacts of involving various forms of external sources as well as governance at the project level within the open innovation context (Tranekjer and Søndergaard, 2013). One of the exceptions revealed that adding external sources might have a negative impact on the project speed and cost (Faems et al., 2009; Leiponen and Helfat, 2010). However, little is understood about the particular mix of external sources and the reason for developing such external collaboration.

\subsection{Complexity and External Collaboration}

In this article we emphasize the inbound knowledge flow from external sources. Remarkably, studies in this field of search strategies and collaborative innovation have concentrated on understanding the governance mode and optimal knowledge source of open innovation in low-knowledge-intensity companies, with a focus on the theory of complexity, because structural innovation issues involve different kinds of complexity.

Complex issues are the same as complex systems, which consist of many different parts that interact in a non-simple way (Flood, 1990). Complex issues include a broad range of remarkably interdependent factors, knowledge and choices sets that should be recombined creatively to provide valuable solutions. Recently different studies have been performed to realize better project and knowledge management and to demonstrate the relationship between project management, especially innovation management, and complexity theory (Cooke Davies et al., 2007; Tepic, et al, 2013; Poutanen et al 2016).

Many recent papers on external collaboration have clearly shown the important role of "complexity" in current research on project management. Such investigations have offered valuable insights theoretically, and have sometimes linked practice and theory. However, it has been assumed to be a kind of black box; the exact elements that lead to complexity in NPD projects have not been described in detail. The necessity of a new paradigm for complex projects has been explained along with the importance of including soft system techniques for modelling a project to support its management (Bosch-Rekveldt et al., 2009). The management of NPD projects needs a framework regarding external collaboration. Such a framework can then be employed to adapt various further development phases of such projects to specific external collaborations to manage projects more effectively. However, currently no solid framework exists, based on both practice and theory, to support the identification and characterization of the external collaboration and to appreciate completely the external collaboration richness of various NPD projects.

\subsection{Structure of the Paper}

In Section 2 the literature survey is explained, and then the results of the case study are presented in Section 3. The achieved framework to incorporate project complexity and external collaboration into NPD projects is provided in Section 4 and discussed further in Section 5. Then Section 6 covers the foreseen application and development of the framework and the study limitations. The conclusions and recommendations for future studies are presented in Section 7.

\section{Literature review}

\subsection{Project Complexity Definitions}

To understand the project complexity elements that contribute to external collaboration, in the first step, complexity definitions were studied. According to the study by Geraldi (2009), the lack of an unambiguous and clear definition of project complexity or projects within a complex context has been reviewed in the literature. Even though project complexity and the surrounding environment definitely exert an impact on critical decisions in project management, such complexity is usually taken intuitively or based on past experiences. As mentioned by Parwani (2002), complexity means studying complex systems of which there is no united accepted definition due to their complexity. Regardless of the inherent difficulty in explaining complexity and various perspectives on complexity (Flood, 1990), a high-level project complexity definition should cover dynamic, structural and interaction factors (Whitty and Maylor, 2009), so complexity in projects can be assumed to be relevant to such dynamic, structural factors and their interaction, being broader than technological or technical domains. The goals and approaches concept (Turner and Cochrane, 1993) categorized projects based on whether the project goals are uncertain or well defined and whether the approaches to achieving such goals are uncertain or well defined. Then Baccarini (1996) presented a review of the project complexity concept within the construction industry in which he suggested that an objective measure of project complexity is relevant to many different interrelated parts, which should be operationalized based on interdependency and differentiation. In addition, he elaborated both technological and organizational complexities. Later Williams (1999) operationalized Turner's and Baccarini's concepts, to study the dimensions of project structural complexity, Williams defined measures of product complexity that influence project complexity. He noted that concurrent engineering leads to more reciprocal interdepend- 
ency, adding to the complexity of the project. Besides the studies conducted by Turner and Baccarini, Williams considered that uncertainty adds to project complexity and thus can be assumed to be a project complexity dimension.

\subsubsection{Softer Aspects and the Environment}

Although the scholars mentioned above emphasized "uncertainty" and "structural complexity", softer aspects and impacts from the environment are considered to affect the level of project complexity (Geraldi and Adlbrecht, 2007; Jaafari, 2003). Later Geraldi developed the concept described earlier by Williams and revealed the difference between the complexity of faith and the complexity of fact (Geraldi and Adlbrecht, 2007) as well as the complexity of interaction. Interaction complexity occurs at the interfaces between organizations and people and any other kind of business interaction (Geraldi and Adlbrecht, 2007; Poutanen et al 2016), which are assumed to be softer aspects that contribute to the total project complexity.

Furthermore, explicit attention to softer aspects was identified in the study by de Bruijn et al. (1996). They considered that project complexity can be broken down into social, technical and organizational complexities. They considered that technical complexity is related to the technological uncertainty, uniqueness and dynamics of projects. Organizational complexity was considered to be relevant to the organization structure and the involved actors and project team, and finally social complexity concerns the involved actors, their interests and consequences and the risks of a project in relation to its environment. In addition, other studies have concluded that the environment is a key contributor to project complexity (Jaafari, 2003; Mason, 2007; Xia and Lee, 2005; KamSing Wong, 2014).

\subsubsection{Gathering Elements from the Literature}

Many literature sources, such as those noted in the previous section, have been utilized to define the elements that can contribute to project complexity. First, literature databases were searched for relevant papers with the keyword "project complexity" (with a publication date of 1996 or later). These papers were reviewed along with the referenced papers. This process was stopped when no new and related referenced papers were identified. The elements contributing to project complexity were listed and then compared to define the key factors. Overall 28 elements contributing to project complexity were obtained from the literature search. To cover other factors, not included in the original ones, for example, uncertainty in methods and goals (Williams, 1999) which are respectively covered in "uncertainty of goals" and "uncertainty of methods" and the level of interdependence among and between processes and products (Tatikonda and Rosenthal, 2000) was covered in "interrelations between technical processes" and "dependencies between tasks". If the elements were too generic, for example uncertainty (Williams, 1999) or dependency on the environment (Vidal and Marle, 2008), they were not added explicitly to the final list; however, they were covered implicitly. Those elements that emphasize how to manage the complexity of a project rather than contributing to project complexity, such as project manager leadership style (Müller and Turner, 2007) or partners' responsibility (Geraldi and Adlbrecht, 2007), were not included in the final list. Further, the elements were developed, defined and refined to enable a comparison with the elements identified in the case studies (Section 3).

\subsection{Sources of Knowledge and Their Combination in NPD Projects}

Although the reasons for including external sources to improve competitive advantages and innovative performance are global, they could be conceptualized in different ways (Sofka and
Grimpe, 2010; Zhao et al 2015; Greco et al., 2015). For instance, Fey and Birkinshaw (2005) concluded that the innovation performance and R\&D of an organization improve through the use of more relational governance, for example relationships with universities and alliance partners. In this regard Keilet al. (2008) demonstrated that greater usage of different open governance modes, such as alliances, JVs and CVC investments, results in improved innovation consequences for organizations. The main intuition, considering formal governance arrangements or informal studies, is that having more external relations and greater search breadth could produce beneficial results for firms that are striving to innovate. In addition, Leiponen and Helfat (2010) showed that more sources of external knowledge result in more innovation as well as improved financial performance. Furthermore, Love et al. (2014) explained the same outcomes by demonstrating how the "breadth of external innovation linkages" could result in better innovation outcomes. One method to conceptualize sources is to consider a number of sources or search breadth, as performed in the study by Laursen and Salter (2006), who identified a limitation to the benefits of adding external partners to the innovation objectives. The negative impact of too much openness might be because of the fact that the company experiences attention allocation issues while improving the number of its external partners (Knudsen and Mortensen, 2011) or higher marginal costs as a result of investigating different types of sources.

\section{Research Question and Method}

To develop a framework as noted earlier, in accordance with theory and practice, the main research question to be answered in the current paper is:

Which elements of NPD projects contribute to project complexity and how should these be included in a framework to characterize external collaboration in NPD projects?

The inductive research approach was selected to answer the research question (Sayer, 1992). This article attempts to synthesize the available empirical and theoretical studies in this field through a new empirical study. Its goal is not to test specific theories that will need a deductive method. Instead, it aims to establish a detailed explanation of external collaboration in new product development projects by utilizing an inductive strategy. First, a survey of the literature was conducted, through which variables that are considered to help different aspects of complexity in NPD projects were collected. Second, case studies were performed in which the factors contributing to project complexity and proposed open innovation practices (OIP) were identified in thirteen interviews from twenty-four projects in small and medium-sized firms that are active in various low-knowledge-intensive industries across Spain. Choosing multiple sources of data via fifteen cases allows triangulation and increases the construct validity of the research (Greene and McClintock, 1985). The interviewees were deliberately not made aware of the results of the literature analysis, and the case studies were then utilized to develop a more detailed framework to incorporate project complexity and external collaboration (specifically OIP) into NPD projects. The intention was to obtain a detailed framework because of its foreseen future application to tailored project management.

\subsection{Data Collection}

Spanish companies with low knowledge intensiveness and a minimum of one NPD project during the last two years in various industries constitute the sample population of this research. Both primary and secondary data sources were gathered, and the data construct validity was verified according to triangulation principles (Greene, 1990). A set of in-depth individual interviews was performed with firms (CEOs and R\&D directors) following the procedure outlined by Eisenhardt (2007) and Yin (2009). Specifically, the interviews were designed to concentrate on NPD pro- 
jects and any kind of external collaboration (with a focus on the open innovation framework) of the firm using semi-structured questions, and face-to-face interviews were performed by corresponding scholars (CEOs and R\&D directors) at each company as well as follow-up telephone interviews. Each of these interviews took 60 to 100 minutes. All of the interviews were recorded and then transcribed, and, to ensure data validity, a database was generated. Overall, over 30 hours of recording and almost 250 transcript pages were gathered in 2016. After the interviews a copy of the case report and transcripts was sent to the interviewees to check them for any possible error to ascertain the authenticity and validity of the gathered data. Moreover, the collected data were triangulated with the information from many evidence sources from both observation and secondary information sources, for example online reports and information, company websites, tweets, material introduced by the informants (internal memos, company brochures and archival data) and news releases to improve the validity of the research (Greene, 1990).

\subsubsection{Case Firm Selection}

Following the suggestions provided by Eisenhardt (1989), we used a multiple-case design with fifteen manufacturing firms within eight industries across Spain. In accordance with Yin (2002), replication logic was applied regarding case selection. Such an information-oriented approach was selected for "maximizing the information utility from small samples and single cases" (Patton, 2002). Together these cases covered less successful and successful projects regarding both meeting the budgets and delivering and scheduling estimates based on the expected results (project performance). A group of factors was considered in the selected projects, for example innovative projects and new business (market/business), and technology was included in different projects ranging from old/proven technologies to new/unproven technologies. In addition, the capital expenditure of such projects ranged from 20 to 600 million euros. Various geographical domains were considered, and the project location varied between remote and industrialized areas (location). The organizations were selected by employing purposeful/theoretical sampling according to Patton (2002) and Yin (2009).

Based on the nature of the current research as well as the NPD literature and open innovation, our main criteria for choosing these firms were: (1) operating in a low-knowledge-intensive industry, (2) having at least 1 NPD project during the last 2 years, (3) having any form of external collaboration in the NPD process, (4) having no more than 250 employees and (5) having an annual turnover not exceeding EUR50 million. In addition, to create the greatest variation among such cases, firms with different ages, sizes and levels of technological development were selected. More than 60 invitation letters were sent to senior managers, and interviews were performed successfully with 15 firms.

\subsubsection{Data analysis and Interpretation}

The selected unit of analysis was a completed new product development project, in which "project" took a broad definition, for example including all of the activities from beginning to close-out (project proposal/initiation, project design/development, project execution/implementation and project commercialization/closeout were excluded).

Following a protocol, 30 semi-structured interviews overall were performed with general managers or their representatives and R\&D directors of a total of 24 projects. During these interviews we asked the candidates open questions about the variables that had contributed to the complexity of a specific NPD project from their perspective. To initiate the interview and contribute further analysis, their definition or interpretation of project complexity was elicited. The candidates did not know the literature results. All of the transcripts were analysed to understand the elements con- tributing to project complexity. A matrix was developed with the elements contributing to the project complexity of each NPD project in the rows and the total of 30 interviews in the columns (for each NPD project). Moreover, the respondents were asked about any kind of external collaboration (governance mode and knowledge source) that they had engaged in during each project to understand the proper mode of external collaboration to handle project complexity.

For the data analysis, we considered this new phenomenon from various perspectives and angles. We identified project complexity causes from various perspectives, for example a lack of capabilities and resources, fast commercialization practices and business model selection. Moreover, we identified the relationship between large and small companies in the NPD process. We used both inductive and deductive methods in this analysis to interpret the cases better and to realize the meaning of theoretical constructs (Eisenhardt, 1989). We used both cross-case and within-case analysis. The within-case analysis includes a description of each case in its own context. This is a critical aspect of studying each case to gain an effective understanding and perspective (Eisenhardt, 1989).

\subsection{Case Study Results}

From the case findings, the variables contributing to project complexity from a practice point of view were collected, complementing or confirming the literature elements. Almost all of the identified elements in the literature survey were confirmed independently by the interviewees without asking explicit questions.

Many aspects contributing to project complexity were identified in these fifteen cases, demonstrating strong support for these aspects specifically. In an effort to summarize them, they were categorized based on the "what", "who" and "how" of the projects as follows:

The "what" of a project regarding the content (the types of complexity in each NPD project);

The "who" of a project regarding the involved and collaborating parties (the number of stakeholders and the different perspectives of stakeholders);

The "how" of a project regarding open innovation practices and governance mode practices (the number of tools and practices).

In analysing these aspects of "what", "who" and "how" in the framework, logically "what" elements were assigned to technical, organizational, environmental and interaction project complexity dimensions. The "who" elements, which are relevant to the involved knowledge sources, were assigned to various NPD projects. The "how" elements were assigned to different practices of open innovation and governance mode that are implemented in NPD projects and that are obtained by a partnership, seller/buyer contract, innovation community and platform or innovation mall (Bellantuono et al., 2013; Faems et al., 2005; Felin and Zenger, 2014; Love and Roper, 1999; Tether and Tajar, 2008). Those elements that describe the "what", "who" and "how" of a project can be considered as key factors that define project complexity dynamics.

Besides the elements listed in Table 1, the practitioners explained some elements that do not contribute to project complexity but instead make it harder to manage a project, such as poor motivation, poor communication and poor relationship management as well as unclarified responsibility distribution. These are known as project management flows that do not contribute to a project's intrinsic complexity because they are manageable; thus, they are not included. 
Table1 : Elements contributing to project complexity from the literature and case study sources

\begin{tabular}{|c|c|}
\hline Technical & Organizational \\
\hline 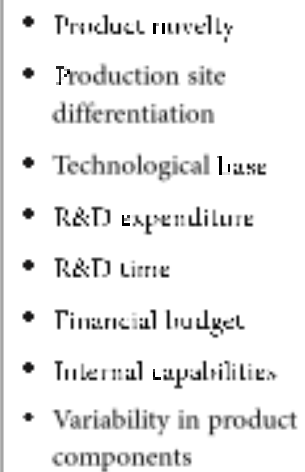 & $\begin{array}{l}\text { - Goal variety } \\
\text { - Goal alignment } \\
\text { - Gosil clitsty } \\
\text { - Goal uncertainty } \\
\text { - Task formalization } \\
\text { - Task diversification } \\
\text { - Task varrialsility } \\
\text { - Task dependency } \\
\text { - Task uncertainty }\end{array}$ \\
\hline
\end{tabular}

\subsection{Proposed Structure for the Framework}

Studying previous investigations and gathering elements from them (Table 1) revealed that it is not just the technological or technical dimensions that define the complexity of a project; environmental and organizational aspects also have a key role. De Bruijn (2003) identified three complexity dimensions: organizational complexity, social complexity and technical complexity. Then they developed a framework including the environmental, organizational and technical elements contributing to project complexity, suggesting the inclusion of various dimensions of project complexity in NPD projects. Baccarini (1996) introduced two forms of complexity in project systems: technological and organizational complexity. Williams (1999) expanded Baccarini's conceptualization of project complexity and then attributed both technological and organizational complexity to structural complexity and assumed uncertainty as the other dimension. Later different scholars designed many different frameworks to realize, classify and evaluate project complexity better from various perspectives. For instance, Geraldi and Adlbrecht (2007) categorized complexity into three types: faith complexity (the complexity in creating something novel, solving new issues or handling high levels of uncertainty), fact complexity (complexity in handling a large amount of independent information) and interaction complexity (complexity relevant to interfaces among locations, for example ambiguity, politics and multiculturalism).

Bosch-Rekveldt et al. (1996) suggested the technical, organizational and environmental (TOE) framework to evaluate engineering projects' complexity. By means of the TOE framework, engineering projects' complexity could be measured by technological complexity (goals, tasks, scope, risk and experience), organizational complexity (size, risk, trust, resource and project team) and environmental complexity (risk, market conditions, location and stakeholders). He et al. (2013) employed a six-category framework for project complexity, consisting of organizational, technological, environmental, goal, information and cultural complexities, to evaluate the complexity of mega-projects.

Considering the main goals of this study, to assign the contributing factors to NPD project complexity, we adopted the TOE model, incorporating with some changes resulting from mixing this model with the model proposed by Geraldi and Adlbrecht (2007), to separate interaction complexity and classify all of the relevant variables in this group. The traditional technical perspective is highly concentrated on the project content $(\mathrm{T})$, the organi-

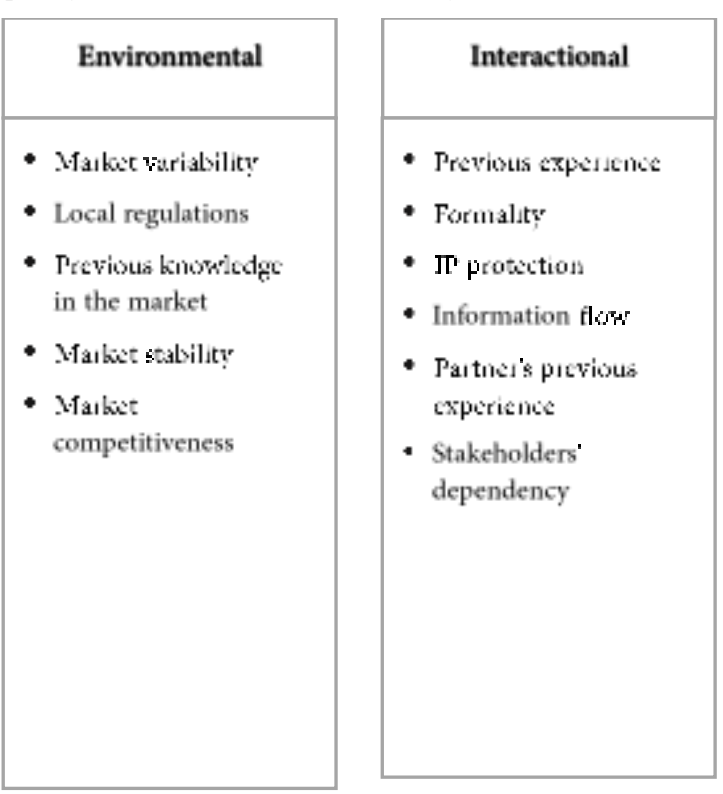

zational view $(\mathrm{O})$ covers softer dimensions, the environmental view (E) includes impacts from the environment and interaction (I) concerns any type of external collaboration proposed during the NPD projects. Therefore, to develop a framework of project complexity, all of the variables were assigned to the technical, the organizational, the environmental or the interaction category (TOEI) (Table 1)

\section{The TOEI Framework for External Collab- oration in New Product Development Projects}

To design a framework for external collaboration in NPD projects from a complexity perspective, the elements obtained from the literature and those from the cases were combined and then recorded. To achieve richness in the framework, however, and to prevent the inclusion of "arbitrary" factors, the following criteria for including elements in the framework were presented.

The final TOEI framework is demonstrated in Table 2 and includes eight $\mathrm{T}$ elements, nine $\mathrm{O}$ elements, five $\mathrm{E}$ elements and six I elements. All of the proposed elements in the T, O, E and I categories have both literature and empirical evidence, providing support for the elements from both practical and theoretical points of view. In the E category, there are three elements with partial empirical evidence (supported by some cases), three of which are relevant to the project location and one of which is relevant to the market condition. The obvious absence of such aspects in other cases might be due to the industry under consideration or due to this research being approached with a deliberate choice from project management insights. This explanation might also apply to those elements with empirically supportive evidence in the $\mathrm{O}$ category, such as HSSE awareness and size (number of locations), and the former is significantly related to the process industry (food and beverage production). We might not find a "quality requirements" element (T category) in previous studies, since little attention has been paid to quality management in the literature (Turner, 2010).

To design the TOEI framework, we kept the richness of the elements contributing to project complexity and external collaboration as identified in previous studies and practices and did not decrease them to a $2 \times 2$ matrix, as performed in a recent study by Whitty and Maylor (2009) on a matrix of structural dynamic interaction. 
The broad TOEI framework, which has three levels consisting of complexity categories, appropriate external collaborators and OIP, suggests an opportunity to argue on different aggregation levels that various aspects of parties and stakeholders who are involved in a project can be a function of the level of project complexity. Moreover, the current set-up allows framework extension for use in all industries.

Therefore, this developed framework could be utilized to evaluate engineering project complexity and to propose some possible external collaboration solutions (source and mode). Evaluating the complexity of a project by its nature is a subjective process in which perceived complexity according to past experiences has a key role. Due to differences in experiences and skills, people who use the framework and evaluate a specific project or phase might reach various conclusions about complexity. Here the main goal of the framework is to obtain better knowledge of projects' complexity and external collaboration. Excluding the absolute scores for various elements, this framework helps to identify the areas of complexity in a particular project. Understanding such areas of complexity, attention will be paid to their management, and, as noted by Geraldi (2009), assessing the complexity itself is a tool to reinforce active management.

Table 2: TOEI framework

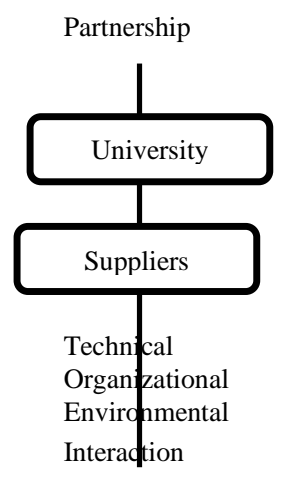

\section{Discussion}

Traditionally, size, novelty and innovativeness have been considered as dominant yet criticized project complexity measures (Williams, 2002). In this paper a few participants pointed out traditional measures as contributing to project complexity. Often aspects that are related to innovativeness and/or novelty, such as the "number of new technological tools and methods" and the "number of stakeholders", were noted; thus, it is important to refine "innovativeness", a general aspect, as a contributor to project complexity and results in implementing the external collaboration. This will support the overall idea of the current study, which is to design a detailed framework to incorporate external collaboration and complexity into NPD projects.

- The TOEI framework includes many elements related to uncertainty and structural complexity. Organizational complexity and technical complexity are both included explicitly as key classifications of project complexity. Most of the elements in the framework's organizational category have a structural character, such as the scope, number of goals and tasks, dependencies between different tasks and so on. In addition, uncertainty of methods and uncertainty of goals are covered in the organizational category elements. The dominant open innovation modes that were obtained from the participants to reduce these types of complexities in the projects are partnerships and some other modes, like communities, which are open innovation modes that can be applied in NPD projects to eliminate some or all of the uncertainty and the project complexity. Appropriate collaborators in this type of complexity are suppliers and in a few cases customers. This shows that suppliers can play an important role in reducing the complexities. Many structural elements are identified in the technical category, for example the Product novelty, Production site differentiation, Technological base, R\&D expenditure and internal capabilities. In addition, the proper and common external collaborators in this part are suppliers and universities and the dominant OI mode partnership.

Here it can be observed that most of the appropriate and common knowledge sources solving the environmental complexity are suppliers and competitors, and the dominant governance modes that are helpful in managing such environmental complexity are partnerships and seller/buyer agreements. In the case of interaction complexity, Suppliers and universities play a role, and the OI
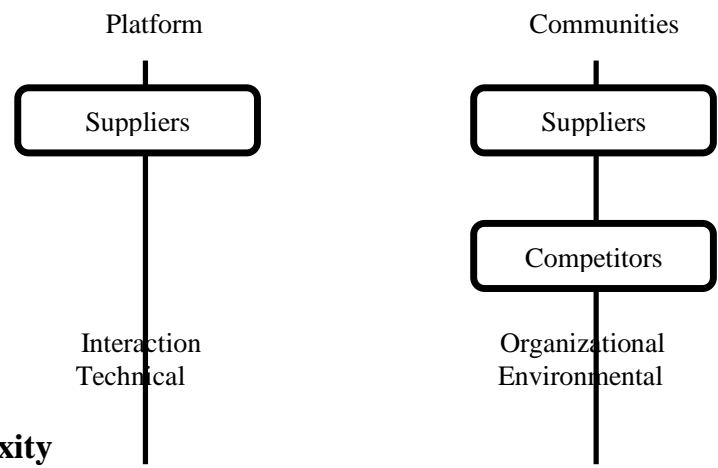

mode is partnerships and platforms. In the TOEI framework, the environment and softer aspects are included explicitly. Softer aspects can be identified in both the environmental and the organizational category in the elements of the TOEI framework, for example the Market variability, Local regulations, Previous knowledge in the market, Market stability and Market competitiveness. Besides, the environmental category covers elements such as the competition level, political influences, required local content and strategic pressure. Here it can be observed that most of the suitable and common knowledge sources addressing the environmental complexity are suppliers and competitors, and the dominant governance modes that are helpful in managing such environmental complexity are partnerships and seller/buyer agreements and in some cases communities. In the case of interaction complexity, suppliers play a role and the OI mode to manage some aspects of this complexity, such as IP protection and/or information flows, is partnerships.

In the TOEI framework, risk is assumed to be a contributor to project complexity. To assert the critical role of risk as a contributor to a project's complexity, the TOEI framework contains a specific risk element in all of the four categories and high risk from the technical, organizational, environmental or interaction perspectives. In addition, the risk aspects are all covered in other different elements of these four categories, particularly topics regarding uncertainty, political influence and the IP protection condition. Here it is clear that the most appropriate and common knowledge sources are suppliers, clients and competitors, and the governance modes of partnerships, seller/buyer agreements and in some cases platforms could be applicable to manage such external collaborations.

To sum up, it can be said that the developed TOEI framework fits the existing critical literature concepts defined in the previous section. In addition, this framework presents an "integrative" list of elements contributing to external collaboration and project complexity in NPD projects. It can integrate various theoretical concepts and practice perspectives.

\section{Managerial Implementation and Develop- ment of the TOEI Framework}

The TOEI framework could be employed as a basis on which to measure NPD projects' complexity. Using the TOEI framework 
for projects provides a good idea of where we should expect the complexity to arise during the project and what the appropriate knowledge sources and governance forms are to handle such complexity. Utilizing the TOEI framework can for example support risk assessment during the early phases of a project. Due to complexity changes within the life cycle of a project, using the framework in different stages of projects needs to be considered to grasp the external collaboration application. Utilizing the complexity evaluation might clarify remarkable problems in a project (Geraldi, 2009). This framework can support the complexity assessment. The main goal of employing the framework is to adapt the frontend development phases of a project better to certain complexities by means of a complexity footprint. In the early stages, a project can be measured regarding the expected complexity, and particular actions can be taken to manage external collaboration. For instance, in a project in which we can expect predominantly technical complexities, we might need different governance modes or knowledge sources from a project in which we expect predominantly environmental complexities. Identifying, understanding and characterizing such complexities via the use of the TOEI framework in the early steps of a project and the next phases are considered to improve project management.

According to the footprint, it might be decided to put more or less effort into open innovation management, process management, risk management and so on in line with the suggested approaches, for example the study by Jaafari (2003) on risk management or the study by Aaltonen et al. (2008) about the management of external partners. According to the ideas of the current literature, external partners can be chosen and/or developed later according to the required competencies to manage specific complexities (Felin and Zenger, 2014).

More TOEI framework developments are predicted to overcome the limitations of the study. The first limitation is the qualitative nature of the study. To design the TOEI framework, the empirical findings revealed data saturation for the analysed cases. To reinforce the existing results, a survey across the industry was conducted with a more quantitative nature. This could not only be considered as a strength of this framework but could also represent a limitation of the study. Thus, we are not able to claim that the TOEI framework is complete.

\section{Conclusion}

To help to manage project complexity and external collaboration, this article provided a framework for defining the external collaboration in NPD projects. This framework is based on both empirical data and literature. Using this framework for a certain project provides an understanding of its complexity, indicating potential methods to manage new product development projects more efficiently. The TOEI framework can be utilized to evaluate a project's complexity and to predefine possible support from external parties. Due to the external collaboration dynamics, we can predict repeated use in different phases of a project.

Applying an inductive method through combining the literature points of view with the elements obtained from30 interviews regarding 15 cases, the TOEI framework provides a broad understanding of external collaboration. Overall 28 elements were identified, contributing to external collaboration and project complexity in the following 4 areas: technical complexity, organizational complexity, environmental complexity and interaction complexity. The number of elements in the framework was not decreased deliberately to explain the richness of project complexity. In the TOEI framework, 4 different levels were identified to facilitate its use: 4 categories known as TOEI, 4 different knowledge sources and 4 modes of external collaboration. It will provide a chance to argue which aspects will make a particular project complex on different levels with different stakeholders and parties involved in the project. This set-up is flexible and allows framework extension, for instance for use in a specific industry.

\section{References}

[1] Aaltonen, K., Jaakko, K., \& Tuomas, O. (2008). Stakeholder salience in global projects. International journal of project management, 26(5), 509-516.

[2] Atuahene-Gima, K. (1995), "An exploratory analysis of the impact of market orientation on new product performance: a contingency approach", Journal of Product Innovation Management, Vol. 12 No. 4, p. 275.

[3] Baccarini, D., 1996. The concept of project complexity-a review. International Journal of

[4] Project Management 14 (4), 201-204

[5] Bahemia, H. and Squire, B. (2010), "A contingent perspective of open innovation in new product development projects", International Journal of Innovation Management, Vol. 14 No. 4, pp. 603 627.

[6] Bell, D. (1999), The Coming of Post-industrial Society: A Venture in Social Forecasting, Basic Books, New York.

[7] Bellantuono, N., Pontrandolfo, P. and Scozzi, B. (2013), "Different practices for open innovation: a context-based approach", Journal of Knowledge Management, Vol. 17 No. 4, pp. 558-568, available at: http://doi.org/10.1108/JKM-03-2013-0180

[8] Bianchi, M., Cavaliere, A., Chiaroni, D., Frattini, F. and Chiesa, V. (2011), "Organisational modes for open innovation in the biopharmaceutical industry: an exploratory analysis", Technovation, Vol. 31 No. 1, pp. 22-33, available at: http://doi.org/10.1016/j.technovation.2010.03.002

[9] Bonaccorsi, A. and Lipparini, A. (1994), "Strategic partnerships in new product development: an Italian case study", Journal of Product Innovation Management, Vol. 11, pp. 134-145, available at: http://doi.org/10.1111/1540-5885.1120134

[10] Bonesso, S., Comacchio, A. and Pizzi, C. (2011), "Technology sourcing decisions in exploratory projects", Technovation, Vol. 31 Nos 10-11, pp. 573-585.

[11] Bosch-Rekveldt, M.G.C. and Mooi, H.G. (2008), "Research into project complexity classification methods", in IPMA 22nd World Congress 2008, Animp Servizi Srl, Rome, pp. 104-108.

[12] Bosch-Rekveldt, M., Mooi, H., Verbraeck, A., Sjoer, E., Wolsing, B. and Gulden, C. (2009), "Mapping project manager's competences to project complexity", in Kakonen, K. (Ed.), IPMA 23rd World Congress, Research Track Human Side of Projects in Modern Business, Project Management Association Finland (PMAF) and VTT Technical Research Centre of Finland, Helsinki.

[13] Cassiman, B., Di Guardo, M.C. and Valentini, G. (2010), "Organizing links with science: cooperate or contract? A project-level analysis", Research Policy, Vol. 39 No. 7, pp. 882-892.

[14] Chesbrough, H. (2003), Open Innovation: The New Imperative for Creating and Profiting from Technology. Harvard Business Press.

[15] Chesbrough, H. (2006), Open Business Models: How to Thrive in the New Innovation Landscape. Harvard Business School Press, Boston, MA

[16] Chesbrough, H. and Crowther, A.K. (2006), "Beyond high tech: early adopters of open innovation in other industries", R\&D Management, Vol. 36 No. 3, pp. 229-236.

[17] Chesbrough, H., Vanhaverbeke, W., West, J. (Eds.), 2006. Open Innovation: Researching a New Paradigm. Oxford University Press, Oxford.

[18] Cooke-Davies, T., Cicmil, S., Crawford, L. and Richardson, K. (2007), "We're not in Kansas anymore, Toto: mapping the strange landscape of complexity theory and its relationship to project management", Project Management Journal, Vol. 38 No. 2, pp. 50-61.

[19] Cooper, R.G. and Kleinschmidt, E.J. (1987), "What makes a new product a winner: success factors at the project level?", R\&D Management, Vol. 17 No. 3, pp. 175-189.

[20] De Bruijn, H., ten Heuvelhof, E., in 't Veld, R.J., 2003. Why Project Management Fails in

[21] Complex Decision Making Processes. Kluwer Academic Publisher, Dordrecht.

[22] ombkins, D. and Dombkins, P. (2008), Contracts for Complex Programs:

[23] A Renaissance of Process, Booksurge Publishing, Charleston.

[24] Eisenhardt, K.M. (1989), "Building theories from case study research”, Academy of Management Review, Vol. 14 No. 4, p. 532. doi: $10.2307 / 258557$

[25] Elmquist, M., Fredberg, T., Ollila, S. (2009) "Exploring the field of open innovation", European Journal of Innovation Management, Vol. 12 Issue: 3 , pp.326-345, https:// doi.org/10.1108/14601060910974219 
[26] Faems, Andries, De Visser and Van Looy (2009), "Technology alliance portfolios and financial performance: disentangling value enhancing and cost increasing effects of open innovation", in Conference Proceedings of the 16th International Product Development Management Conference.

[27] Faems, D., Van Looy, B. and Debackere, K. (2005), "Interorganizational collaboration and innovation: toward a portfolio approach", Journal of Product Innovation Management, Vol. 22 No. 3, pp. 238-250.

[28] Felin, T. and Zenger, T.R. (2014), "Closed or open innovation? Problem solving and the governance choice", Research Policy, Vol. 43 No. 5, pp. 914-925, available at http://doi.org/10.1016/j.respol.2013.09.006

[29] Flood, R.L. (1990), Liberating Systems Theory, Plenum Press, New York.

[30] Geraldi, J.G. (2009), "What complexity assessments can tell us about projects: dialogue between conception and perception", Technology Analysis \& Strategic Management, Vol. 21 No. 5, pp. 665-678.

[31] Geraldi, J.G. and Adlbrecht, G. (2007), "On faith, fact, and interaction in projects", Project Management Journal, Vol. 38 No. 1, pp. $32-43$.

[32] Gerwin, D., Kumar, V. and Pal, S. (1992), "Transfer of advanced manufacturing technology from Canadian universities to industry", Technology Transfer, Vol. 12, pp. 57-67 (Spring-Summer)

[33] Greco, M., Grimaldi, M., Cricelli, Z. (2015) "Open innovation actions and innovation performance: A literature review of European empirical evidence", European Journal of Innovation Management, Vol. 18 Issue: 2, pp.150-171, https://doi.org/10.1108/EJIM-072013-0074

[34] Greene, Jennifer, and Charles McClintock. (1985) "Triangulation in evaluation: Design and analysis issues." Evaluation Review 9.5: 523-545.

[35] Hakansson, H.K. and Eriksson, A.-K. (1993), "Getting innovations out of supplier networks", Journal of Business-to-Business Marketing, Vol. 1 No. 3, p. 3.

[36] Hamel, G. (1991), "Competition for competence and inter-partne learning within international strategic alliances", Strategic Management Journal, Vol. 12 No. 4, pp. 83-103.

[37] Handfield, R. and Lawson, B. (2007), "Integrating suppliers into new product development", Research Technology Management, Vol. 50 No. 5 , p. 44

[38] Hass, K. (2007), "Introducing the project complexity model. A new approach to diagnosing and managing projects - part 1 of 2", PM World Today, Vol. IX No. VII, pp. 1-8.

[39] Henkel, J., 2006. Selective revealing in open innovation processes: the case of embedded Linux. Research Policy 35 (7), 953-969.

[40] Henttonen, K., Lehtimäki, H. (2017) "Open innovation in SMEs: Collaboration modes and strategies for commercialization in technology-intensive companies in forestry industry", European Journal of Innovation Management, Vol. 20 Issue: 2, pp.329-347, https://doi.org/10.1108/ EJIM-06-2015-0047

[41] Hippel, E.V. (1978), "Successful industrial products from customer ideas", Journal of Marketing, Vol. 42 No. 1, p. 39.

[42] Hoang, H. and Rothaermel, F.T. (2010), "Leveraging internal and external experience: exploration, exploitation, and $\mathrm{R} \& \mathrm{D}$ project performance", Strategic Management Journal, Vol. 31 No. 7, pp. 734-758.

[43] Inkpen, A.C. and Tsang, E.W.K. (2005), "Social capital, networks and knowledge transfer", Academy of Management Review, Vol. 30 No. 1 , pp. $146-165$

[44] Ireland, R. D., Hitt, M. A., \& Vaidyanath, D. (2002). Alliance management as a source of competitive advantage. Journal of Management, 28(3), 413-446.

[45] Jaafari, A. (2003), "Project management in the age of complexity and change", Project Management Journal, Vol. 34 No. 4, pp. 4757.

[46] Kam-Sing Wong, S. (2014) "Impacts of environmental turbulence on entrepreneurial orientation and new product success", European Journal of Innovation Management, Vol. 17 Issue: 2, pp.229-249, https:// doi.org/10.1108/EJIM-04-2013-0032

[47] Karl-Heinz Leitner, (2015) "Pathways for the co-evolution of new product development and strategy formation processes: Empirical evidence from major Austrian innovations", European Journal of Innovation Management, Vol. 18 Issue: 2, pp.172-194, https://doi.org/10.1108/EJIM-01-2014-0002

[48] Karmarkar, U. (2004), "Will you survive the services revolution?" Harvard Business Review, Vol. 82 No. 6, pp. 100-107.
[49] Keil, T., Maula, M.V., Schildt, H.A., Zahra, S.A., 2008. The effect of governance modes and relatedness of external business development activities on innovative performance. Strategic Management Journal 29 (8), 895-907

[50] Kessler, E.H., Bierly, P.E. and Gopalakrishnan, S. (2000), "Internal vs. external learning in new product development: effects on speed, costs and competitive advantage", R\&D Management, Vol. 30 No 3, pp. 213-224.

[51] Knudsen, M.P. (2007), "The relative importance of interfirm relationships and knowledge transfer for new product development success", Journal of Product Innovation Management, Vol. 24 No. 2, pp. 117-138.

[52] Knudsen, M.P. and Mortensen, T.B. (2011), "Some immediate but negative - effects of openness on product development performance", Technovation, Vol. 31 No. 1, pp. 54-64.

[53] Lau, A.K.W., Tang, E. and Yam, R.C.M. (2010), "Effects of supplier and customer integration on product innovation and performance: empirical evidence in Hong Kong manufacturers", Journal of Product Innovation Management, Vol. 27 No. 5, pp. 761-777.

[54] Laursen, K. (2011), "User-producer interaction as a driver of innovation: costs and advantages in an open innovation model", Science \& Public Policy (SPP), Vol. 38 No. 9, pp. 713-723.

[55] Laursen, K. and Salter, A. (2005), "The paradox of openness: appropriability and the use of external sources of knowledge for innovation", paper presented at the Academy of Management Conference, 5-10 August, Honolulu, Hawaii, USA.

[56] Laursen, K. and Salter, A. (2006), "Open for innovation: the role of openness in explaining innovation performance among UK manufacturing firms", Strategic Management Journal, Vol. 27 No. 2, pp. 131-150.

[57] Leiponen, A. and Helfat, C.E. (2010), "Innovation objectives, knowledge sources, and the benefits of breadth", Strategic Management Journal, Vol. 31 No. 2, pp. 224-236.

[58] Lichtenthaler, U. and Ernst, H. (2009), "Opening up the innovation process: the role of technology aggressiveness", R\&D Management Vol. 39 No. 1, pp. 38-54.

[59] Love, J.H. and Roper, S. (1999), "The determinants of innovation: R\&D, technology transfer and networking effects", Review of Industrial Organization, Vol. 15 No. 1, pp.43-64

[60] Love J. H., Roper S. and Vahter P. (2014). Learning from openness: the dynamics of breadth in external innovation linkages, Strategic Management Journal, forthcoming

[61] March, J.G. (1991), "Exploration and exploitation in organizational learning", Organization Science, Vol. 2 No. 1, pp. 71-87.

[62] Mason, R.B. (2007), "The external environment's effect on management and strategy - a complexity theory approach", Management Decision, Vol. 45 No. 1, pp. 10-28.

[63] Maylor, H., Vidgen, R. and Carver, S. (2008), "Managerial complexity in project based operations: a grounded model and its implications for practice", Project Management Journal, Vol. 39, S15S26 Supplement.

[64] Miotti, L. and Sachwald, F. (2003), “Co-operative R\&D: why and with whom? An integrated framework of analysis", Research Policy, Vol. 32 No. 8, pp. 1481-1499.

[65] Müller, R., Turner, J.R., 2007. Matching the project manager's leadership style to project

[66] type. International Journal of Project Management 25 (1), 21-32.

[67] Nieto, M.J. and Santamaría, L. (2007), "The importance of diverse collaborative networks for the novelty of product innovation", Technovation, Vol. 27 Nos 6-7, pp. 367-377.

[68] Parwani, R.R., 2002. Complexity: An Introduction. National University of Singapore,

[69] Singapore.

[70] Patton, M. Q. (2002). Designing qualitative studies. Qualitative research and evaluation

[71] methods, 3, 230-246.

[72] Petersen, K. J., Handfield, R. B., \& Ragatz, G. L. (2003). A model of supplier integration into new product development. Journal of product innovation management, 20(4), 284-299.

[73] Poutanen P., Soliman W., Ståhle P., (2016) "The complexity of innovation: an assessment and review of the complexity perspective", European Journal of Innovation Management, Vol. 19 Issue: 2, pp.189-213, https://doi.org/10.1108/EJIM-03-2014-0036

[74] Powell, W.W., Koput, K.W. and Smith-Doerr, L. (1996), "Interorganizational collaboration and the locus of innovation: networks of learning in biotechnology", Administrative Science Quarterly, Vol 41 No. 1 , pp. $116-145$. 
[75] Ragatz, G. L., Handfield, R. B., \& Petersen, K. J. (2002). Benefits associated with supplier integration into new product development under conditions of technology uncertainty. Journal of business research, 55(5), 389-400.

[76] Santoro, M.D. (2000), "Success breeds success: the linkage between relationship intensity and tangible outcomes in industryuniversity collaborative ventures", Journal of High Technology Management Research, Vol. 11 No. 2, pp. 255-273.

[77] Sayer, Andrew. "1992. Method in Social Science. A realist approach. 2. painos." (1984).

[78] Schulttze, U. and Stabell, C. (2004), "Knowing what you don't know? Discourses and contradictions in knowledge management research", Journal of Management Studies, Vol. 41

[79] No. 4, pp. 549-573.

[80] Sofka, W. and Grimpe, C. (2009), "Specialized search and innovation performance - evidence across Europe", R\&D Management, Vol. 40 No. 3, pp. 310-323.

[81] Tatikonda, M.V. and Rosenthal, S.R. (2000), "Technology novelty, project complexity and product development project execution success: a deeper look at task uncertainty in product innovation", IEEE Transactions on Engineering Management, Vol. 47 No. 1, pp. 74 87.

[82] Tepic, M. Kemp, R. Omta, O. Fortuin, F. (2013) "Complexities in innovation management in companies from the European industry: A path model of innovation project performance determinants", European Journal of Innovation Management, Vol. 16 Issue: 4, pp.517-550, https://doi.org/10.1108/ EJIM-05-2012-0053

[83] Tether, B. S., \& Tajar, A. (2008). Beyond industry-university links: Sourcing knowledge for innovation from consultants, private research organisations and the public science-base. Research Policy, 37(6), 1079-1095.

[84] Tidd, J. and Hull, F.M. (2003), Services Innovation: Organisationa Responses to Technological Opportunities and Market Imperatives, Imperial College Press, London.

[85] Tranekjer, T.L. and Søndergaard, H.A. (2013), "Sources of innovation, their combinations and strengths - benefits at the NPD project level", International Journal of Technology Management, Vol. 61 Nos 3/4, 205-236, available at http://doi.org/10.1504/IJTM.2013.052668

[86] Turner, J.R. (2010), "Evolution of project management research as evidenced by papers published in the International Journal of Project Management", International Journal of Project Management, Vol. 28 No. 1, pp. 1-6.

[87] Turner, J.R. and Cochrane, R.A. (1993), "Goals-and-methods matrix: coping with projects with ill-defined goals and/or methods of achieving them", International Journal of Project Management, Vol. 11 No. 2, pp. 93-102.

[88] Un, C.A., Cuervo-Cazurra, A. and Asakawa, K. (2010), "R\&D collaborations and product innovation", Journal of Product Innovation Management, Vol. 27 No. 5, pp. 673-689.

[89] Van de Vrande, V., Vanhaverbeke, W. and Gassmann, O. (2010), "Broadening the scope of open innovation: past research, current state and future directions", International Journal of Technology Management, Vol. 52, pp. 221-235.

[90] Varis, M., and Littunen, H. (2010), 'Types of Innovation, Sources of Information and Performance in Entrepreneurial SMEs,' European Journal of Innovation Management, 13, 128- 154.

[91] Vega-Jurado, J., Gutiérrez-Gracia, A. and Fernández-de-Lucio, I. (2009), "Does external knowledge sourcing matter for innovation? Evidence from the Spanish manufacturing industry", Industrial \& Corporate Change, Vol. 18 No. 4, pp. 637-670.

[92] Veliyath, R. and Fitzgerald, E. (2000), "Firm capabilities, business strategies, customer preferences, and hypercompetitive arenas: the sustainability of competitive advantages with implications for firm competitiveness", Competitiveness Review, Vol. 10 No. 1, pp. 5682.

[93] Vidal, L.-A. and Marle, F. (2008), "Understanding project complexity: implications on project management", Kybernetes, Vol. 37 No. 8, pp. 1094-1110.

[94] West, J. and Bogers, M. (2014), "Profiting from external innovation: a review of research on open innovation", paper presented at the 9th International Open and User Innovation Workshop, Vienna, Austria, available at: http://ssrn.com/abstract $=1949520$

[95] West, J., Gallagher, S., 2006. Challenges of open innovation: the paradox of firm investment in open-source software. R\&D Management 36 (3), 319-331.
[96] West, J., Salter, A., Vanhaverbeke, W. and Chesbrough, H. (2014), "Open innovation: the next decade", Research Policy, Vol. 43 No. 5 pp. 805-811. http://doi.org/10.1016/j.respol.2014.03.001

[97] Whitty, S.J. and Maylor, H. (2009), "And then came complex project management (revised)", International Journal of Project Management, Vol. 27 No. 3, pp. 304-310.

[98] Williams, T.M. (1999), "The need for new paradigms for complex projects", International Journal of Project Management, Vol. 17 No. 5, pp. 269-273.

[99] Williams, T.M. (2002), Modelling Complex Projects, John Wiley \& Sons, London

[100] Xia, W. and Lee, G. (2005), "Complexity of information systems development projects: conceptualization and measurement development", Journal of Management Information Systems, Vol. 22 No. 1 , pp. $45-83$.

[101] Yin, R.K. (2009), Case Study Research: Design and Methods (Google eBook), SAGE, available at: http://books.google.com/books?id=FzawIAdilHkC\&pgis $=1$

[102] Zhao, S., Sun, Y. and Xu, X. (2015), "Research on open innovation performance: a review", Information Technology and Management, available at: http://doi.org/10.1007/s10799-015-0231-7 